\title{
Discovery and Mapping of the Triton Seep Site, Redondo Knoll: Fluid Flow and Microbial Colonization Within an Oxygen Minimum Zone
}

OPEN ACCESS

Edited by:

Randi D. Rotjan

Boston University, United States

Reviewed by:

Florence Schubotz,

University of Bremen, Germany

Haley M. Sapers,

California Institute of Technology,

United States

*Correspondence:

Christopher R. German

cgerman@whoi.edu

Specialty section:

This article was submitted to

Deep-Sea Environments and Ecology,

a section of the journal

Frontiers in Marine Science

Received: 02 April 2019

Accepted: 10 February 2020

Published: 21 February 2020

Citation:

Wagner JKS, Smart C and

German CR (2020) Discovery and Mapping of the Triton Seep Site,

Redondo Knoll: Fluid Flow and Microbial Colonization Within an

Oxygen Minimum Zone.

Front. Mar. Sci. 7:108.

doi: 10.3389/fmars.2020.00108
Jamie K. S. Wagner ${ }^{1}$, Clara Smart ${ }^{2}$ and Christopher R. German ${ }^{3 *}$

1 Department of Biology, Duke University, Durham, NC, United States, ${ }^{2}$ Applied Physics Laboratory, Johns Hopkins University, Laurel, MD, United States, ${ }^{3}$ Woods Hole Oceanographic Institution, Woods Hole, MA, United States

This paper examines a deep-water ( 900 m) cold-seep discovered in a low oxygen environment $\sim 30 \mathrm{~km}$ off the California coast in 2015 during an EN Nautilus telepresence-enabled cruise. This Triton site was initially detected from bubble flares identified via shipboard multibeam sonar and was then confirmed visually using the remotely operated vehicle (ROV) Hercules. High resolution mapping (to $1 \mathrm{~cm}$ resolution) and co-registered imaging has provided us with a comprehensive site overview - both of the geologic setting and the extent of the associated microbial colonization. The Triton site represents an active cold-seep where microorganisms can act as primary producers at the base of a chemosynthesis-driven food chain. But it is also located near the core of a local oxygen minimum zone (OMZ), averaging $<0.75 \mu \mathrm{M}$ oxygen, which is significantly below average ocean levels (180-270 $\mu \mathrm{M})$ and, indeed, extreme even among OMZs as a whole which are defined to occur at all oxygen concentrations $<22 \mu \mathrm{M}$. Extensive microbial mats, extending for $>100 \mathrm{~m}$ across the seafloor, dominate the site, while typical seep-endemic macro-fauna were noticeably absent from our co-registered photographic and high-resolution mapping surveys - especially when compared to all adjacent seep sites within the same California Borderlands region. While such absences of abundant macro-fauna could be attributable to variations in the availability of dissolved oxygen in the overlying water column this need not necessarily be the case. An alternate possibility is that the zonation in microbial activity that is readily observable at the seafloor at Triton reflects, instead, a concentric pattern of radially diminishing fluxes of reductants from the underlying seafloor. This unusual but readily accessible discovery, in close proximity to Los Angeles harbor, provides an intriguing new natural laboratory at which to examine biogeochemical and microbiological interactions associated with the functioning of cold seep ecosystems within an OMZ.

Keywords: cold seep, oxygen minimum zone, California Borderlands, microbial mats, continental margin

\section{INTRODUCTION}

Historically, our understanding of cold seep distributions and their attendant chemosynthetic fauna (e.g. Sibuet and Olu, 1998) was limited due to the cost, time, and technology required for systematic search patterns. However, more accessible and higher resolution modern multibeam bathymetric approaches allow detection of gas-rich bubble flares in the water column rising above cold-seep 
sites that can be traced very efficiently back to their seafloor source (Merewether et al., 1985; Weber et al., 2012; Skarke et al., 2014; Levin et al., 2016). In this study, we utilized these techniques to locate a unique environment off the Los Angeles coast, which, despite its proximity to a major U.S. city, had yet to be visually explored. In this paper, we report the discovery of this $\sim 30 \mathrm{~m} \times 40 \mathrm{~m}$ Triton site, which exhibits the dual redox-active characteristics of being a gas-rich seep site that is located within the core of an oxygen minimum zone (OMZ).

Along the Pacific coast of North and South America the majority of cold seeps located, to-date, have been characterized by various combinations of soft sediments, exposed authigenic carbonates, methane-rich fluid flow, microbial mats, and endemic megafauna. In the case of cold seeps located along the U.S. West Coast, the predominant megafauna reported from such sites are vesicomyid clams, although vestimentiferan tubeworms and diverse less abundant megafauna (including solemyid clams, galatheid crabs, limpets, and snails) have also been described, as well as a diversity of macrofaunal and meiofaunal species (e.g. Barry et al., 1996; Levin et al., 2003, 2010; Grupe et al., 2015).

Oxygen minimum zones are widespread along the eastern Pacific Ocean, where the dissolved oxygen concentration falls $<22 \mu \mathrm{M}$, equivalent to $0.5 \mathrm{mg} / \mathrm{L}$ (Helly and Levin, 2004; Karstensen et al., 2008), in comparison to 180-270 $\mu \mathrm{M}$ (4$6 \mathrm{mg} / \mathrm{L})$ typically found in the ocean. Strong upwelling of nutrients along the continental slope results in rapid growth of phytoplankton and zooplankton biomass, which then sinks and decomposes, overwhelming the rate of dissolved oxygen resupply during the degradation process (Wyrtki, 1962; Karstensen et al., 2008). In combination with reduced circulation and mixing, stratification can create a persistent zone of low oxygen levels within the water column, typically within the $200-1000 \mathrm{~m}$ depth range (Levin, 2003). Along the Eastern Pacific boundary, such OMZs repeatedly intersect the continental slope, affecting benthic ecosystems by limiting fauna and decreasing diversity within the zones. Helly and Levin (2004) estimated that there are $>1$ million $\mathrm{km}^{2}$ of shelf and seafloor along the margins of the eastern Pacific, western Atlantic, and Indian Ocean basins under permanent OMZ conditions.

In this study, we report the discovery of a particularly interesting site of seafloor fluid flow that appears unique, at least among the California Borderlands seep-sites: a chemosynthetic ecosystem located at the base of Redondo Knoll, $\sim 30 \mathrm{~km}$ from Los Angeles, that is situated at the same depth as the core of the local OMZ. Using state of the art mapping techniques we have achieved high resolution imaging and mapping (at better than $1 \mathrm{~cm}$ resolution), which is rare for such environments and has allowed us to complete a detailed examination of the site's surface morphology and its associated microbial colonization without perturbing the pristine ecosystem.

\section{GEOLOGICAL SETTING}

The California Borderlands extend up to $200 \mathrm{~km}$ offshore from the densely populated California coastline and display an unusually rugged topography for a continental margin.
They are made up of a series of deep (500-2,000 m) basins separated by shallow ridges - some of which outcrop above sea level as islands, such as Catalina Island. Surprisingly, this area of seafloor has only been sparsely investigated, and while there has been extensive mapping undertaken by ships passing through the region along transits of opportunity (the area underlies a major shipping route between Los Angeles harbor and the port of San Francisco) what has remained lacking, to date, is a comprehensive and systematic campaign to map this complex region of seafloor, despite its proximity to metropolitan Los Angeles. Geologically, the California Borderlands are a component of the same Pacific/North American tectonic plate boundary as the San Andreas Fault (SAF). But while the latter, which lies above sea-level, is now increasingly well characterized, about $20 \%$ of all plate motion associated with the SAF system takes place offshore within the relatively poorly studied California Borderlands. This includes multiple sub-orthogonal faults that extend from onshore through the Los Angeles metropolitan area to offshore across the shelf and margin, representing a major potential earthquake and coastal tsunami hazard. While much of the seafloor of the California Borderlands remains unmapped, our work illustrates that the tectonic faults crossing this highly tectonized region of seafloor also have the potential to host a diversity of styles of seafloor fluid flow, sustaining associated chemosynthetic biological communities.

The Redondo Knoll (Figure 1) represents just one of numerous uplifted blocks of seafloor within the larger California Borderlands area. It is centered at $\sim 33^{\circ} 45^{\prime} \mathrm{N}, 118^{\circ} 40^{\prime} \mathrm{W}, \sim 30 \mathrm{~km}$

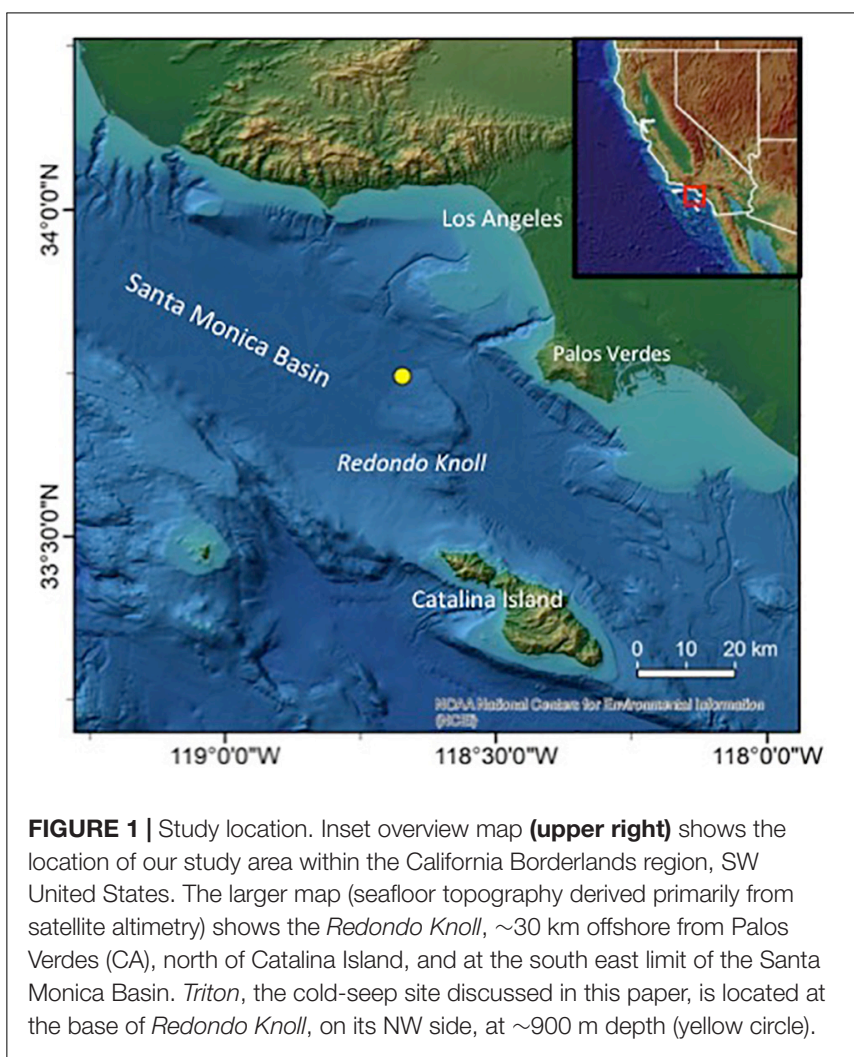


North of Catalina Island's most northwestern limit and $<30 \mathrm{~km}$ west of Palos Verdes, CA, United States. As such, it defines the southeastern limit of the deep Santa Monica Basin, which extends NW for $\geq 70 \mathrm{~km}$. A flare appearing within the multibeam water column data, diagnostic of active gas bubble release, was identified toward the base of the Knoll on its NW side (i.e. at the south-east limit of the Santa Barbara basin) during multibeam mapping within the California Borderlands region in 2015. Tracing the acoustic signals to the seafloor indicated a location immediately adjacent to the primary shipping lanes between Los Angeles and San Francisco. The source of the active fluid flow, together with associated microbial colonization, was confirmed at $\sim 900 \mathrm{~m}$ depth during a subsequent dive with the ROV Hercules.

\section{MATERIALS AND METHODS}

\section{E/V Nautilus}

The tandem ROVs Hercules (Figure 2A) and Argus, deployed from E/V Nautilus (Ocean Exploration Trust), were used for exploring, imaging, and surveying the Triton site. Data for this study were collected during E/V Nautilus Cruise NA067 in August 2015, on ROV Hercules dive H1461 (Levin et al., 2016). The Triton seep site, hosting active fluid flow and associated microbial colonization, was centered at $33^{\circ} 45^{\prime} \mathrm{N}, 118^{\circ} 40^{\prime} \mathrm{W}$.

Seafloor mapping was initially conducted from the E/V Nautilus using a hull mounted Kongsberg EM 302 multibeam sonar system. Operating at $30 \mathrm{~Hz}$, this system is capable of gathering bathymetric data at depths of up to $7000 \mathrm{~m}$, resulting in grid resolutions of up to $1 \%$ of water depth. Resulting seafloor data products include bathymetry maps and acoustic backscatter, which can be useful for investigating geologic processes at the seafloor including changes in sediment cover (thickness and composition). Additionally, data collected within the water column can indicate differentials in acoustic impedance, thus allowing for the detection of rising "bubble-flares" indicative of gas-rich seafloor seep activity (e.g., Merewether et al., 1985). Bubbles rising from a vigorous seep are typically apparent within two to five sequential multibeam water column fan images and can be identified at rise-heights of tens to hundreds of meters above the seafloor. Correlation between acoustic water column images and the ships differential GPS allows for the positions of the seeps that produce these detected gas bubble "flares" to be located precisely at the underlying seafloor. In this study, sonar data from the EM302 multibeam system revealed bubbles rising through the water column over the NW corner of Redondo Knoll. Once it had been confirmed to be a previously unknown seep site, the target was located and selected for detailed seafloor exploration using the ROV Hercules.

\section{ROV Hercules Systems}

A forward mounted high definition video camera (Deep Sea Power and Light) was used for site reconnaissance and for recording video footage. Additional sensors included a Sea-Bird FastCAT 49 conductivity, temperature, and depth sensor (CTD), an Aanderaa 3830 Oxygen sensor, and a temperature probe $\left(0-450^{\circ} \mathrm{C}\right)$.

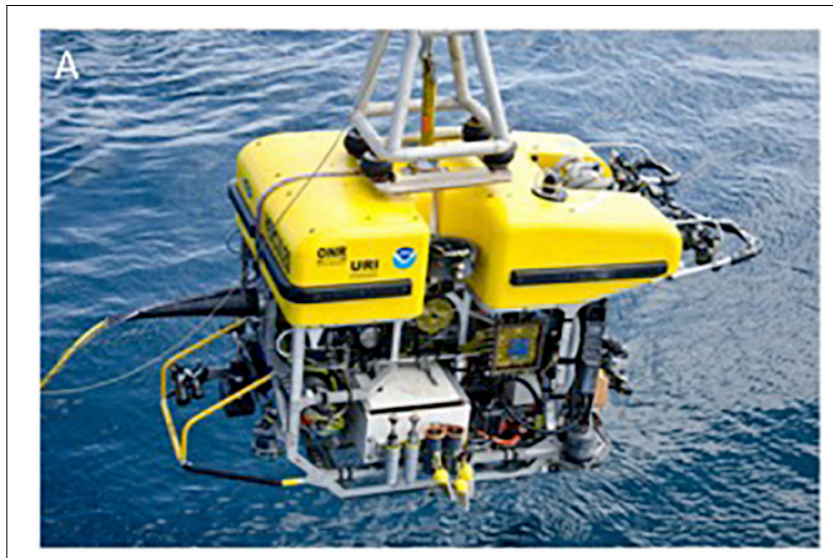

B

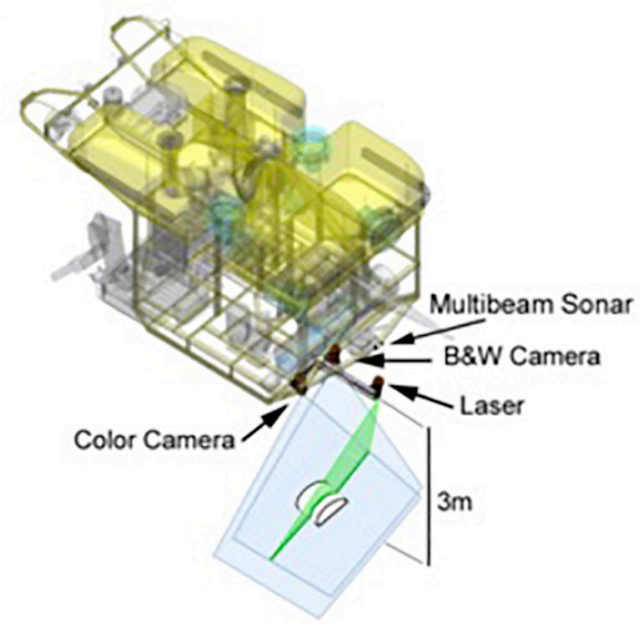

FIGURE 2 | ROV Hercules (A) during deployment. The imaging suite is mounted on the aft of the vehicle. (B) CAD drawing showing the high resolution imaging system and sensor footprints.

Mapping and imaging surveys at the Triton site were conducted using a state-of-the-art high resolution imaging suite (Inglis et al., 2012; Roman et al., 2012) mounted on the ROV Hercules (Figure 2). Optical and acoustic data for centimeter resolution bathymetric and photographic maps were collected to gain a spatial understanding of the site both visually and bathymetrically. Color and monochromatic stereo images were collected with two 12-bit Prosilica GC1380 computer vision cameras. The structured light laser sensor, for high resolution bathymetric data collection, consists of a 12-bit mono Prosilica GC1380 camera and verged $100 \mathrm{~mW} 532 \mathrm{~nm}$ Coherent PowerLine sheet laser mounted on a rigid frame with known relative geometry. The stereo camera frame rate was $0.33 \mathrm{~Hz}$, interlacing images with the structured light laser system, collecting images at $20 \mathrm{~Hz}$. Acoustic bathymetric data were collected by a $1350 \mathrm{kHz}$ BlueView multibeam sonar system. Placing the imaging suite at the back of the vehicle separated it from the forward mounted operational $\mathrm{HD}$ video camera 
and lights to minimize lighting artifacts. All imaging data were collected simultaneously and, hence, were both navigationally and temporally co-registered.

During high resolution imaging surveys, a closed loop control system on the ROV was used to complete organized track-line surveys at prescribed velocities and altitudes. Highresolution mapping data that could be gridded at a subcentimeter scale were collected from $3 \mathrm{~m}$ above the seafloor along track-lines completed at a velocity of $0.15-0.20 \mathrm{~m} / \mathrm{s}$. The navigation sensor suite included a $600 \mathrm{kHz}$ Teledyne RDI Doppler velocity log (DVL), a Paroscientific pressure depth sensor, and an IXSEA Octans fiber optic gyro system for heading and attitude information.

Note that all capabilities of the investigations described here were non-invasive, by design, and involved no physical interactions with the seafloor. Because the site discovery was unexpected and because we did not have the equipment and expertise aboard ship to fully process any samples for fluid geochemistry or microbiology it was decided to preserve the site in pristine and unperturbed condition to await dedicated future process-oriented studies.

\section{RESULTS}

\section{Overview of the Triton Seep Site}

The Triton site located just off the California coast exhibits features characteristic of a cold seep fluid flow site hosting associated microbial colonization but it is simultaneously located at the core of an OMZ. An initial exploration transect of the area with the ROV, oriented approximately from East to West, progressed from flat tan sediment onto a region of rougher, and rising/shallowing seafloor covered in extensive white microbial mats (Figure 3A). Continuing west toward a bubble target detected by Hercules' forward-looking sonar, the ROV next encountered a sharp drop in terrain that was coincident with a marked change in the color of the microbial mats draped over the seafloor from white to a bright yellow-orange color (Figure 3B). Toward the center of this low-lying area covered with thick yellow-orange mats (subsequently revealed to be the floor of a quasi-circular "crater") were a series of deeper $\sim 1-2$ m diameter pits exposing dark gray sediment that were devoid of any visible evidence for microbial life. Vigorous plumes of bubbles were observed rising from at least one of these pits (Figure 3C), coincident with where the original shipboard multibeam survey had predicted that the source of the water column "flare" should occur. Subsequently, an imaging survey of the entire site (see next section) revealed that this same observational sequence was repeated in all directions away from the center of the site with quasi-radial symmetry (Figures 4, 5). The microbial mats extended for $\sim 135 \mathrm{~m}$ in the longest dimension. Located at close to $900 \mathrm{~m}$ water depth, close to the base of the East Pacific OMZ (Helly and Levin, 2004), what was perhaps just as notable as the presence of abundant microbial mats across this seep site was the corresponding absence of abundant endemic seep megafauna. This represented a striking contrast to adjacent seep sites at other depths studied within the California Borderlands region as part

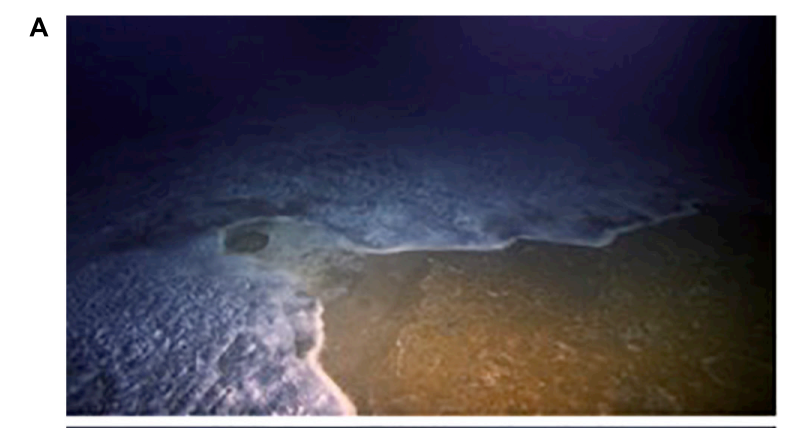

B

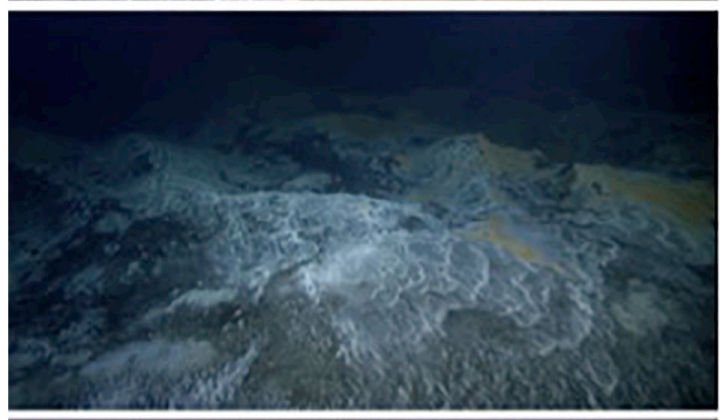

C

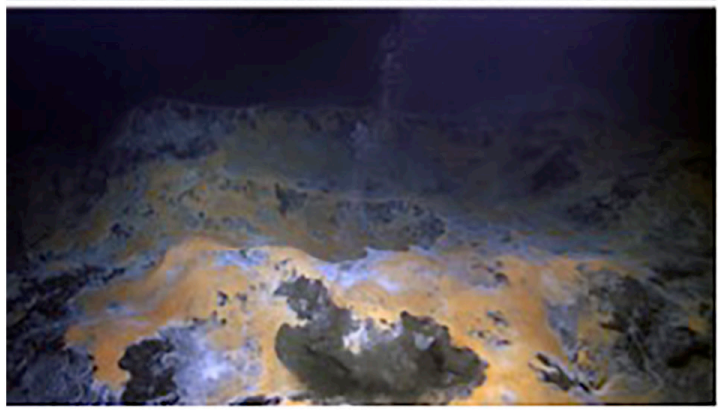

FIGURE 3 | Triton seep overview. Still images captured from the forward looking HD Video Camera mounted on ROV Hercules during a preliminary $\sim$ E-W reconnaissance transect across the Triton mud volcano seep site at the base of Redondo Knoll. (A) At the periphery of the site, monotonous brown sediment transitions into rising terrain covered in extensive white microbial mats; (B) closer to the center of the site, there is a sharp transition across the rim of a pronounced depression ( $10 \mathrm{~m}$ in diameter, $0.5 \mathrm{~m}$ deep) from white to brightly colored yellow-orange microbial mat covering the inner walls and floor of the mud volcano; and $\mathbf{( C )}$ at the center of the site, a vigorous bubble plume was observed rising from a pit of dark gray sediment that was devoid of any visible microbial life. Copyright Ocean Exploration Trust, Inc.

of the same expedition (Levin et al., 2016). The only evidence for multi-cellular organisms observed at the Triton site were dark red cnidarians (jellies) swimming in the overlying water column and small kelp falls, covered in microbial mat, at the seafloor.

\section{High-Resolution Spatial Surveys of the Triton Seep Site}

Following our initial ROV reconnaissance transect, a $30 \mathrm{~m} \times 40 \mathrm{~m}$ area that included the actively bubbling seep was mapped using the high-resolution imaging suite outlined in the Materials and Methods section. A north-south "raster" survey pattern was established, which was completed at a vehicle altitude of $3 \mathrm{~m}$ above the seafloor and at a programed velocity 


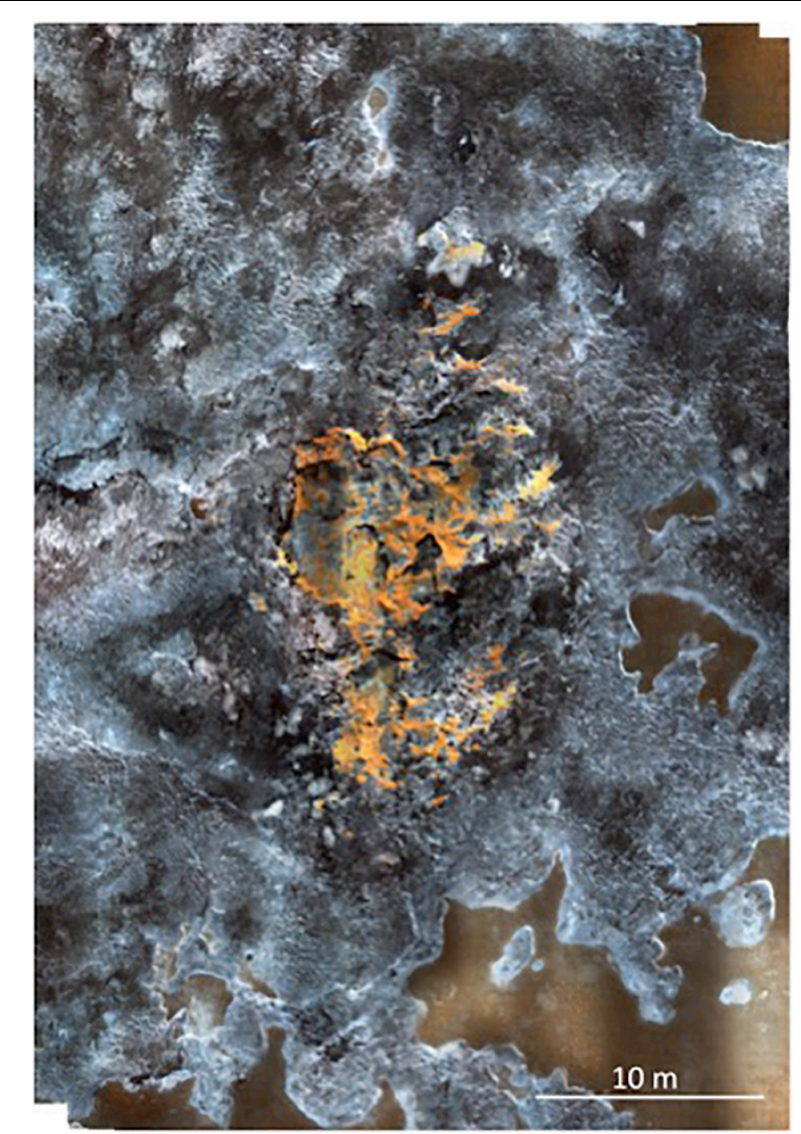

FIGURE 4 | Photomosaic of the Triton cold seep site. An $\sim 30 \times 40 \mathrm{~m}$ area centered on the site of active fluid flow was selected for co-registered imaging and high resolution mapping surveys. This photomosaic is comprised of approximately 1500 color images. Within this image white microbial mats cover the gently upward sloping seafloor while within the center of the image, the steep-walled depression around the active seep exhibits higher rugosity and the microbial mats coating the walls and floor of that depression are a bright yellow-orange in color. Images were taken at an elevation of $3 \mathrm{~m}$ above the seafloor. Co-registered bathymetry is shown in Figure 5.

of $0.18 \mathrm{~m} / \mathrm{s}$. The resulting photomosaic (Figure 4) comprises approximately 1500 separate color still images. To create a bathymetric map from the same survey, the structured light laser data were gridded to centimeter level resolution and co-registered with ROV vehicle navigation. Track lines were spaced to ensure $30-40 \%$ overlap between adjacent survey lines to ensure complete coverage of the site (Figure 5). In situ sensor data (including CTD and oxygen) were collected from the ROV along the same track lines to provide co-registered information about overlying water column properties (Figure 6). Consideration of the imagery and bathymetric data, together, reveals a near concentric pattern in which an extensive area covered in white microbial mat surrounds a 1-2 m lower lying central region, $\sim 10 \mathrm{~m}$ in diameter, that is covered in bright yellow-orange microbial mat. It is within this central region that discrete sub-circular pits are observed lined with dark gray sediments and lacking any evidence of microbial colonization.
These barren pits display the most vigorous bubble plume activity (Figure 3C). Across the entire survey, dissolved oxygen concentrations were close to the limits of detection at $<1.0 \mu \mathrm{M}$, representing $<0.2 \%$ of saturation levels at the ocean surface. Beyond the limits of the imaged area, the surrounding habitat consisted of soft tan sediment, which was much flatter than the rugose (1-2 $\mathrm{m}$ topography) region associated with active fluid flow (Figures 4, 5). No evidence for authigenic carbonate was observed throughout the dive.

\section{Time-Variable Fluid Flow at the Triton Seep Site}

Active gas bubbles at the NW limit of Redondo Knoll were originally detected, as discussed in Section 2.2, from the shipmounted multibeam system. Imaging of the cold seep site included an initial reconnaissance of the site, which revealed a steady stream of rising bubbles early in the dive both in our forward-looking sonar and as imaged directly from our forward-looking camera at 03:24:09 GMT (Figure 3C). During the subsequent high-resolution mapping and imaging survey centered on the same site, bubble-flow remained visible but, on a like-for-like basis, appeared much less vigorous based on the forward-looking $\mathrm{HD}$ video monitored by the watch leaders when passing over the same site (04:35:43 GMT). Upon completion of the survey, the ROV returned to these same central pits to conduct temperature probe measurements only to find that, by 05:26 GMT, active fluid flow and gas bubbling at this location had (at least temporarily) ceased (Figure 7).

\section{DISCUSSION}

\section{Temporal Variability in Seafloor Fluid Flow at the Triton Seep Site}

The time-variant nature of flow that we observed at the Triton seep site aligns directly with the local diurnal tidal cycle. In our study of how fluid flow at Triton varied while we were onsite on 16 August 2015 (vigorous at 03:24 GMT; diminished at 04:35 GMT; absent at 05:26GMT), the highest flux-rates that we observed, at the very start of our ROV dive, occurred at $\sim 4 \mathrm{~h}$ after local low-tide along the adjacent Los Angeles shoreline (23:20 GMT, 15 August; $49 \mathrm{~cm}$ height). Our subsequent observation that all flow had ceased coincided almost perfectly with local peak high tide (05:21 GMT, 16 August, $171 \mathrm{~cm}$ height). Tidalrelated changes in seafloor fluid-flow have been well documented for decades at submarine hydrothermal vent-sites (e.g., Johnson et al., 1988; Little et al., 1988) and a similar correlation between methane flux and tidal height at cold seeps has subsequently been hypothesized to arise from a causative mechanism in which fluxes vary according to a reduction in hydrostatic pressure at low tide (e.g., Boles et al., 2001; Torres et al., 2002; Krabbenhöft et al., 2010). It is entirely consistent with such a hypothesis that the flow of bubbles from the seafloor at Triton only ceased completely as peak high tide was approached. Had this ROV dive (H1461) been extended beyond an operationally imposed vehicle recovery time, we can hypothesize that the flow of bubbles from this site 


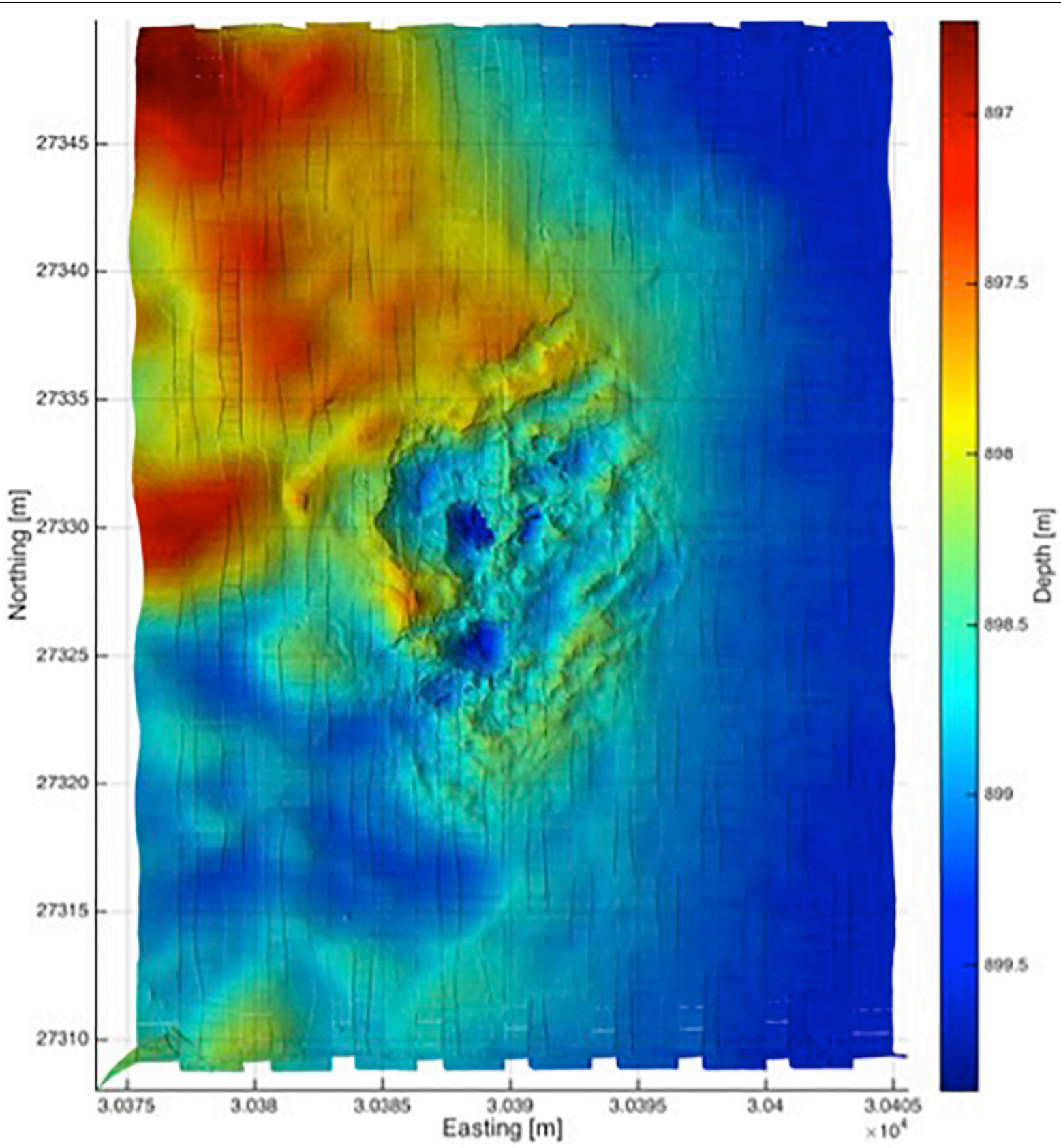

FIGURE 5 | High resolution bathymetric map of the Triton cold seep site. This map was created using structured light laser data, and gridded to 1-cm level resolution. Bathymetry was obtained while the ROV surveyed at $3 \mathrm{~m}$ above the seafloor. The bathymetric data shown here are co-registered with the photomosaic shown in Figure 4.

would have been seen to resume within as little as $1 \mathrm{~h}$ of further on-bottom time beyond peak local high-tide.

\section{Microbiological Distributions Across the Triton Seep Site}

Because Triton appeared to represent such an unusual setting among the California Borderlands sites investigated during our cruise (Levin et al., 2016), a conscious decision was made during our sole exploratory dive not to conduct any seafloor sampling that might perturb this otherwise pristine site. While that absence of sampling precludes definitive determination of what the dominant microbial species responsible for the extensive colonization of the seafloor at Triton might be, we do note the following: (a) chemoautotrophic bacteria that thrive on hydrogen sulfide commonly form mats at all sites of active seepage along ocean margins (Levin et al., 2003); (b) Beggiatoa spp. bacteria are one of the most common types of sulfide-oxidizing and 


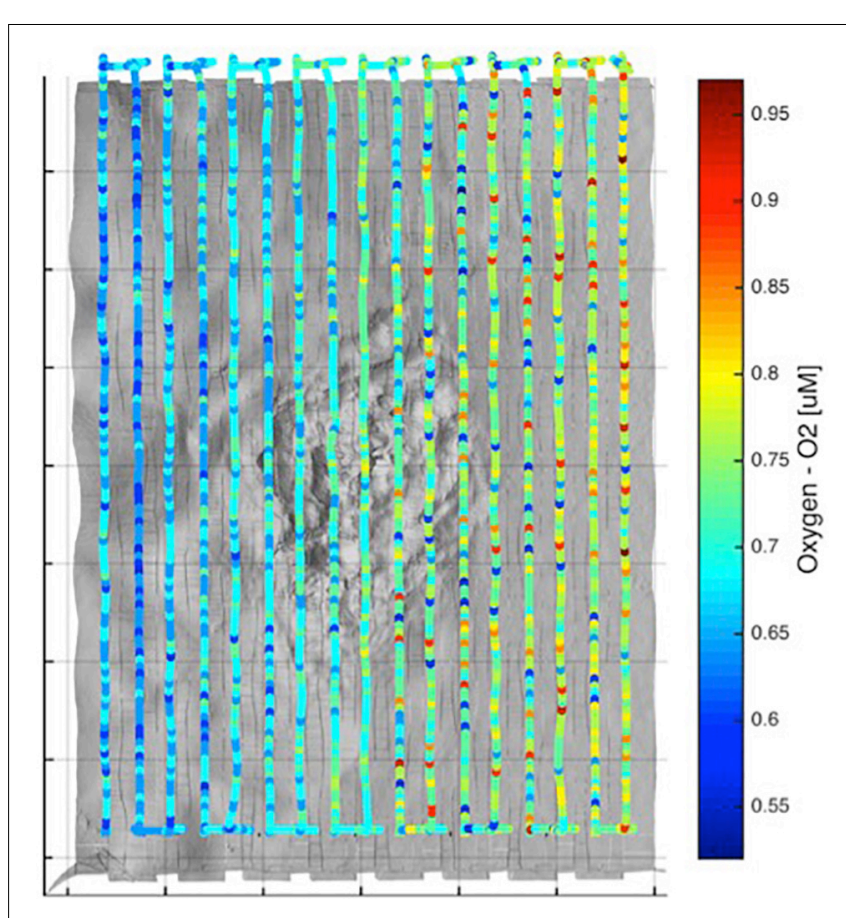

FIGURE 6 | Tracklines with dissolved oxygen concentrations overlying the Triton cold seep site. Very low oxygen levels were observed at all locations overlying the Triton cold seep site, as measured from $3 \mathrm{~m}$ above the seafloor during surveying. All data projected here are co-registered with the photographic and multibeam surveys shown in Figures 4, 5. mat-forming microbial species found at seeps worldwide (Larkin and Henk, 1996; Gilhooly et al., 2007; Fischer et al., 2012); (c) Beggiatoa spp. bacteria are also known to thrive in OMZs (Jørgensen and Gallardo, 1999; Schulz et al., 1999); (d) the morphology of the mats observed at the Triton site match closely to the characteristics identified as diagnostic of Beggiatoa spp. bacteria: a large (20-200 $\mu \mathrm{m}$ diameter, up to $2 \mathrm{~cm}$ in length) filamentous sulfur-oxidizing organism (Larkin and Henk, 1996). Pursuing this line of reasoning further, mats of Beggiatoa spp. have also been found, previously, to exhibit "color-coded" bimodal distributions similar to those shown here, with orange coloration at areas of greater sulfide flux, and white coloration at areas of lower sulfide flux at seep-sites in the Gulf of Mexico and at the Pakistan margin (Gilhooly et al., 2007; Fischer et al., 2012). It will be interesting to investigate, in future dives, whether the microbial mats distributed extensively across the Triton cold seep site are dominated by Beggiatoa spp. sulfide-oxidizing bacteria.

\section{Absence of Seep-Endemic Macrofauna at the Triton Seep Site}

While Triton lacked any endemic seep-related megafauna and macrofauna, the adjacent Point Dume seep site, located $\sim 40 \mathrm{~km}$ to the $\mathrm{NW}$, was found to host dense populations of vesicomyid and lucinid clams, aggregations of polychaetes, foraminifera, galatheid crabs, anemones, soles, rockfish, and catsharks (Levin et al., 2016). Importantly, however, the Point

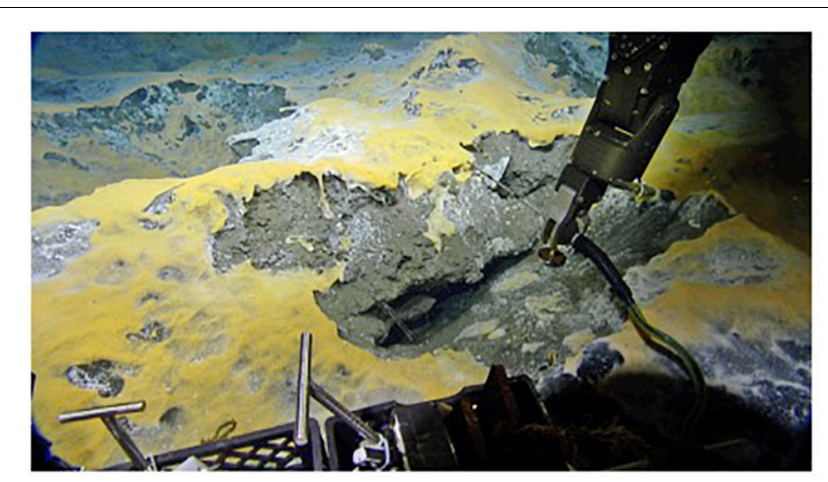

FIGURE 7 | Temporal variability in seafloor fluid flow at the Triton seep site. Temperature probe deployment at the same deep pit site as imaged in Figure 3C, but bubbling had ceased by 05:26 GMT. Copyright Ocean Exploration Trust, Inc.

Dume site was 150-200 m shallower than Redondo Knoll, at 700$750 \mathrm{~m}$ water depth rather than $900 \mathrm{~m}$. This meant that it was poised at a shallower depth within the East Pacific OMZ, such that the benthos at that location were exposed to significantly higher dissolved oxygen concentrations of 1-5 $\mu \mathrm{M}$ when compared to the $\sim 0.75 \mu \mathrm{M}$ that is more typical of seafloor conditions at the $\sim 900 \mathrm{~m}$ Triton site. One possibility, therefore, is that the notably lower levels of dissolved oxygen found at the Redondo Knoll seafloor could be responsible for the notable absence of seependemic macro-fauna at this specific California Borderlands seep site. Certainly, prior work in OMZ regions off Chile, Pakistan, and the United States (Oregon) has indicated that community structure at seep sites can vary depending on their location within an OMZ: near the fringes (where oxygen levels are higher) or closer to the core (where oxygen levels approach zero). For example, some seep sites with nothing but microbial mats have been observed at OMZ settings off Chile and Pakistan, while others have also hosted vesicomyid clams, and polychaete worms (Sellanes et al., 2010; Fischer et al., 2012; Himmler et al., 2015). Two lines of reasoning suggest that we should exhibit caution before attributing an absence of visually observed seependemic macro-fauna at Triton to its positioning within the $\mathrm{OMZ}$, however. First, in the absence of any direct sampling, it is possible that small fauna were present on the seafloor at Triton but fell below the spatial resolution of the imaging undertaken using our high definition cameras (we calculate $\sim 3 \mathrm{~mm}$ /pixel resolution for our $3 \mathrm{~m}$ altitude survey, thus any organism $<1 \mathrm{~cm}$ across may not have been well resolved). Alternately, there might also have been fauna present at the Triton site but living beneath the seafloor within the underlying sediments. At Hydrate Ridge, on the Oregon Margin, Guilini et al. (2012) have studied the abundance and species richness of OMZtolerant nematodes found in sediment cores collected at and away from cold seep fluid flow settings indicating that the absence of observed multi-cellular organisms at the seafloor at the Triton site does not preclude the presence of abundant sediment infauna. Importantly, however, in that same study cold seep sites were identified along Hydrate Ridge that were at depths directly 
comparable to that of the Triton site (700-900 m) which meant that they were comparably close to the core of the local OMZ $(\sim 800 \mathrm{~m})$ but they were characterized, variably, by the presence of microbial mats alone - as seen at the Triton site - or by clam beds replete with the vesicomyids Calyptogenica pacifica and Calyptogenica klimeri (Sahling et al., 2002; Levin et al., 2003). Thus, while our observations of the seafloor at the Redondo Knoll and adjacent Point Dume seep sites, on consecutive days during our 2015 cruise, revealed clear and distinct differences in the abundances of seep-endemic macrofauna present, it may be an over-simplification to attribute those variations exclusively to differences in the depths of their seafloor settings and associated ambient deep ocean oxygen levels, above or at the core of the local OMZ. What else, then, could account for the absence of abundant seep-endemic macro-fauna at the Triton seep site?

\section{The Importance of Fluid Flow Rates at the Triton Seep Site?}

The presence of an area of seafloor thickly carpeted with microbial mats but with a region at its center that is devoid of microbial life, at the Triton seep site, is somewhat reminiscent of what has previously been reported, extensively, from another active and vigorous cold seep site at an ocean margin setting: the Haakon Mosby mud volcano (de Beer et al., 2006; Jørgensen and Boetius, 2007; Feseker et al., 2014). There, albeit over a larger $(\sim 1 \mathrm{~km})$ diameter, a central region that is devoid of microbial colonization hosts active bubble-fluxing from the seafloor while a surrounding zone with less active fluid flow is colonized extensively by thick microbial mats. In that system, it has been concluded that the flow rate of methane from the seabed toward the center of the mud volcano is so fast that it precludes any anaerobic oxidation of methane within the sediment pore-fluids prior to release from the seafloor. Consequently, insufficient sulfide is generated in the pore fluids to sustain sulfur oxidizing Beggiatoa spp. bacteria and, hence, bacterial mats are absent from the center of the site. Instead, it is only toward the outer reaches of the mud volcano at Haakon Mosby that flux rates of dissolved methane are sufficiently slow (and concomitant pore-water sulfide concentrations are correspondingly high) that extensive microbial mats are observed (de Beer et al., 2006). Could concentric zonation of flow rate at the Triton seep site explain both the absence and distributions of microbial mats reported here? Two further lines of reasoning suggest that this might be the case.

First, while the core of the Triton cold seep site appears completely devoid of microbial life, when compared to our observations of the surrounding seafloor, there is also a further distinction that is immediately apparent in Figure 4 between the yellow-orange coloration of the microbial mats draping the inner walls and floor of the Triton cold seep system and the white coloration of the microbial mats draping the outer flanks of the site, onlapping the surrounding tan sediments. In the Gulf of Mexico, exactly the same bi-modal distribution of coloring has been reported for Beggiatoa spp. bacterial mats surrounding a seafloor cold-seep site and, at that location, the readily visible color change was shown to coincide with a marked decrease in sulfide concentrations from $>6 \mathrm{nM}$ in the sediments underlying yellow-orange mats to concentrations that were a factor of 5 lower beneath white-colored mats of the same species (Gilhooly et al., 2007). The same bi-modal color distribution has also been reported for microbial mats along the Pakistan margin (Fischer et al., 2012) where pore fluid sulfide concentrations were $\sim 6 \mathrm{mM}$ beneath orange mats but significantly lower $(\sim 0.75 \mathrm{mM})$ beneath white mats. At Hydrate Ridge, an even more marked variation in seafloor colonization of cold seeps in an OMZ setting is apparent as a function of net fluid flux rates and $\mathrm{H}_{2} \mathrm{~S}$ concentrations. There, sulfide concentrations in excess of $28 \mathrm{mM}$ have been reported from the uppermost sediments directly underlying sites characterized by microbial mats only, whereas clam bed sites at the same depths within the $\mathrm{OMZ}$ are characterized by much lower flux rates and much lower $\mathrm{H}_{2} \mathrm{~S}$ concentrations at the same depths into the underlying sediments (Sahling et al., 2002; Valentine et al., 2005; Sommer et al., 2007).

Combining the above arguments with our direct observations of concentric microbial color-zonation and gas bubbles streaming from the seafloor it seems evident that the maximum flux of methane from the Triton seep site must occur at the center of our survey area. We can then hypothesize that the surrounding yellow-orange mats correspond to regions of sufficiently less vigorous flow that anaerobic methane oxidation can occur within the underlying sediment pore-spaces, together with concomitant hydrogen sulfide generation. Extending the analogy to what has been observed at other cold seeps, we would then infer that the outer concentric region that is dominated by white microbial mats at the Triton seep site (Figure 4) represents a zone of still lower net fluid flux rates and hydrogen sulfide generation - but that even here the conditions remain too hostile for colonization by seependemic macro-fauna. In this scenario, it would be the rates of methane flux and sulfide generation associated with the Triton seep that preclude colonization of the site by endemic macro-fauna rather than just the low oxygen concentrations found here, at the core of the OMZ. Continuing the analogy further, the central dark gray sediment pits that are devoid of microbial life at Triton, coincident with where vigorous bubble activity was observed, would correspond to environments reported elsewhere (e.g. at the center of the Haakon Mosby Mud Volcano) where the physical flux of reductants exiting the underlying sediments is so high that it overwhelms the ability of any chemosynthetic microorganisms to exploit redox couples at the seafloor leading to a central "dead zone" (de Beer et al., 2006). The occurrence of such extremes at Triton both for macro-faunal and microbial colonization is, of course, all the more plausible precisely because of the extremely low dissolved oxygen concentrations observed across the entire survey area (Figure 6).

\section{CONCLUSION}

We report the discovery of a new cold seep site, Triton, that is located at $\sim 900 \mathrm{~m}$ water depth and within $<30 \mathrm{~km}$ from 
Los Angeles in the California Borderlands region. The site is distinct from adjacent cold seep sites that were already known in this area in two regards. First, Triton is deeper than other previously studied seep sites in the California Borderlands region and, hence, lies closer toward the core of the OMZ with lower concentrations of dissolved oxygen in the overlying water column $(<0.75 \mu \mathrm{M})$ placing this site toward the lower bounds of known OMZ settings worldwide. Second, the site is notably devoid of the same seep-endemic macro-fauna that are observed in abundance at other seep-hosted chemosynthetic ecosystems in the California Borderlands region. At Triton, what is observed is a concentric distribution of features: a rugose and concentric morphologic feature, $\sim 30-40 \mathrm{~m}$ in radial extent, slopes upward toward the center and is covered in white microbial mats. At the rim of a central "crater" the color of this microbial mat switches to a bright yellow-orange color that drapes the inward facing walls and floor of the central depression which measures $\sim 10 \mathrm{~m}$ across. Within that central depression lie a series of deeper pits of the order 1-2 $\mathrm{m}$ in diameter and up to $1 \mathrm{~m}$ deep that are devoid of microbial life and from which active (but time-varying) gas bubbling is observed. From a comparison with other cold seep systems associated with OMZs, both in the California Borderlands and along other ocean margin settings, we hypothesize that both the absence of abundant macrofauna at the seafloor at Triton, and the concentric nature of the distributions of microorganisms may be attributable to variations in the flux of reductants from the underlying seafloor (with highest fluxes at the center) rather than the low oxygen concentrations in the overlying water column. The discovery of this new and intriguing study site, in such a readily accessible location close to Los Angeles harbor, provides a novel natural laboratory at which to test this and other hypotheses concerning the functioning of, and biogeochemical-microbiological interactions at, cold seep ecosystems associated with OMZs.

\section{REFERENCES}

Barry, J. P., Greene, H. G., Orange, D. L., Baxter, C. H., Robison, B. H., Kochevar, R. E., et al. (1996). Biologic and geologic characteristics of cold seeps in Monterey Bay, California. Deep Sea Res. I Oceanogr. Res. Pap. 43, 1739-1762. doi: 10.1016/s0967-0637(96)00075-1

Boles, J. R., Clark, J. F., Leifer, I., and Washburn, L. (2001). Temporal variation in natural methane seep rate due to tides, coal oil point area, California. J. Geophys. Res. Oceans 106, 27077-27086. doi: 10.1029/2000jc000774

de Beer, D., Sauter, E., Niemann, H., Karl, N., Foucher, J.-P., Witte, U., et al. (2006). In situ fluxes and zonation of microbial activity in surface sediments of the Haakon Mosby Mud Volcano. Limnol. Oceanogr. 51, 1315-1331. doi: 10.4319/lo.2006.51.3.1315

Feseker, T., Boetius, A., Wenzhöfer, F., Blandin, J., Olu, K., Yoerger, D. R., et al. (2014). Eruption of a deep-sea mud volcano triggers rapid sediment movement. Nat. Commun. 5:5385. doi: 10.1038/ncomms6385

Fischer, D., Sahling, H., Nöthen, K., Bohrmann, G., Zabel, M., and Kasten, S. (2012). Interaction between hydrocarbon seepage, chemosynthetic communities, and bottom water redox at cold seeps of the Makran accretionary prism: insights from habitat-specific pore water sampling and modeling. Biogeosciences 9, 2013-2031. doi: 10.5194/bg-9-2013-2012

Gilhooly, W. P., Carney, R. S., and Macko, S. A. (2007). Relationships between sulfide-oxidizing bacterial mats and their carbon sources in northern Gulf of

\section{DATA AVAILABILITY STATEMENT}

The datasets generated for this study are available on request to the corresponding author.

\section{AUTHOR CONTRIBUTIONS}

JW conducted the analysis of the biological and fluid flow data. CS conducted the mapping surveys and performed the analysis of the bathymetric, photo, ROV sensor, and navigation data. CG led the ROV dive to the study site and provided geological insights. All authors contributed to the writing of the manuscript.

\section{FUNDING}

Ship time was funded by NOAA - Office of Exploration and Research and the Ocean Exploration Trust. This material is based upon work supported by a National Science Foundation Graduate Research Fellowship (to JW), the Office of Naval Research (to CS), and NASA's Astrobiology program (to CG).

\section{ACKNOWLEDGMENTS}

We would like to acknowledge the scientists, shore scientists, and crew of the E/V Nautilus. This research used data provided by the Ocean Exploration Trust's Nautilus Exploration Program, Cruise NA067. We thank Dr. Lisa Levin and Dr. Mark Rausher's Lab for helpful feedback and Dr. Chris Roman's Lab at URI for high resolution imaging capability. We particularly thank Guest Associate Editor Randi Rotjan and two reviewers who helped us streamline and greatly improve the focus of this manuscript.

Mexico cold seeps. Organ. Geochem. 38, 380-393. doi: 10.1016/j.orggeochem. 2006.06.005

Grupe, B. M., Krach, M. L., Pasulka, A. L., Maloney, J. M., Levin, L. A., and Frieder, C. A. (2015). Methane seep ecosystem functions and services from a recently discovered southern California seep. Mar. Ecol. 36, 91-108. doi: $10.1111 /$ maec. 12243

Guilini, K., Levin, L. A., and Vanreusel, A. (2012). Cold seep and oxygen minimum zone associated sources of margin heterogeneity affect benthic assemblages, diversity and nutrition at the cascadian margin (NE Pacific Ocean). Prog. Oceanogr. 96, 77-92. doi: 10.1016/j.pocean.2011.10.003

Helly, J. J., and Levin, L. A. (2004). Global distribution of naturally occurring marine hypoxia on continental margins. Deep Sea Res. I Oceanogr. Res. Pap. 51, 1159-1168. doi: 10.1016/j.dsr.2004.03.009

Himmler, T., Birgel, D., Bayon, G., Pape, T., Ge, L., Bohrmann, G., et al. (2015). Formation of seep carbonates along the Makran convergent margin, northern Arabian Sea and a molecular and isotopic approach to constrain the carbon isotopic composition of parent methane. Chem. Geol. 415, 102-117. doi: 10. 1016/j.chemgeo.2015.09.016

Inglis, G., Smart, C., Vaughn, J., and Roman, C. (2012). “A pipeline for structured light bathymetric mapping," in Proceedings of the IEEE/RSJ International Conference Intelligent Robots and Systems, Portugal.

Johnson, K. S., Childress, J. J., and Beehler, C. L. (1988). Short-term temperature variability in the rose garden hydrothermal vent field: an unstable deep-sea 
environment. Deep Sea Res. A Oceanogr. Res. Pap. 35, 1711-1721. doi: 10.1016/ 0198-0149(88)90045-3

Jørgensen, B. B., and Boetius, A. (2007). Feast and famine-microbial life in the deep-sea bed. Nat. Rev. Microbiol. 5:770. doi: 10.1038/nrmicro1745

Jørgensen, B. B., and Gallardo, V. A. (1999). Thioploca spp: filamentous sulfur bacteria with nitrate vacuoles. FEMS Microbiol. Ecol. 28, 301-313. doi: 10.1111/ j.1574-6941.1999.tb00585.x

Karstensen, J., Stramma, L., and Visbeck, M. (2008). Oxygen minimum zones in the eastern tropical Atlantic and Pacific oceans. Prog. Oceanogr. 77, 331-350. doi: $10.1016 /$ j.pocean.2007.05.009

Krabbenhöft, A., Netzeband, G. L., Bialas, J., and Papenberg, C. (2010). Episodic methane concentrations at seep sites on the upper slope Opouawe Bank, southern Hikurangi Margin, New Zealand. Mar. Geol. 272, 71-78. doi: 10.1016/ j.margeo.2009.08.001

Larkin, J. M., and Henk, M. C. (1996). Filamentous sulfide-oxidizing bacteria at hydrocarbon seeps of the Gulf of Mexico. Microsc. Res. Tech. 33, 23-31. doi: 10.1002/(sici)1097-0029(199601)33:1<23::aid-jemt4>3.0.co;2-1

Levin, L., Girguis, P. R., German, C. R., Brennan, M. L., Tuzun, S., Wagner, J., et al. (2016). Exploration and discovery of methane seeps and associated communities in the California Borderland. Oceanography 28, 40-43.

Levin, L. A. (2003). Oxygen minimum zone benthos: adaptation and community response to hypoxia. Oceanogr. Mar. Biol. Annu. Rev. 41, 1-45.

Levin, L. A., Mendoza, G. F., Gonzalez, J. P., Thurber, A. R., and Cordes, E. E. (2010). Diversity of bathyal macrofauna on the northeastern Pacific margin: the influence of methane seeps and oxygen minimum zones. Mar. Ecol. 31, 94-110. doi: 10.1111/j.1439-0485.2009.00335.x

Levin, L. A., Ziebis, W., Mendoza, G. F., Growney, V. A., Tryon, M. D., Brown, K. M., et al. (2003). Spatial heterogeneity of macrofauna at northern California methane seeps: influence of sulfide concentration and fluid flow. Mar. Ecol. Prog. Ser. 265, 123-139. doi: 10.3354/meps265123

Little, S. A., Stolzenbach, K. D., and Grassle, F. J. (1988). Tidal current effects on temperature in diffuse hydrothermal flow: Guaymas Basin. Geophys. Res. Lett. 15, 1491-1494. doi: 10.1029/gl015i013p01491

Merewether, R., Olsson, M. S., and Lonsdale, P. (1985). Acoustically detected hydrocarbon plumes rising from 2-km depths in Guaymas Basin, Gulf of California. J. Geophys. Res. Solid Earth 90, 3075-3085.

Roman, C., Inglis, G., Vaughn, J. I., Smart, C., Douillard, B., and Williams, S. (2012). The development of high-resolution seafloor mapping techniques. Oceanography 25, 42-45.

Sahling, H., Rickert, D., Lee, R. W., Linke, P., and Suess, E. (2002). Macrofaunal community structure and sulfide flux at gas hydrate deposits from the Cascadia convergent margin, NE Pacific. Mar. Ecol. Prog. Ser. 231, 121-138. doi: 10.3354/ meps231121
Schulz, H. N., Brinkhoff, T., Ferdelman, T. G., Hernandez, M., Teske, A., and Jørgensen, B. B. (1999). Dense populations of a giant sulfur bacterium in Namibian shelf sediments. Science 284, 493-495. doi: 10.1126/science.284.5413. 493

Sellanes, J., Neira, C., Quiroga, E., and Teixido, N. (2010). Diversity patterns along and across the Chilean margin: a continental slope encompassing oxygen gradients and methane seep benthic habitats. Mar. Ecol. 31, 111-124. doi: 10.1111/j.1439-0485.2009.00332.x

Sibuet, M., and Olu, K. (1998). Biogeography, biodiversity and fluid dependence of deep-sea cold-seep communities at active and passive margins. Deep Sea Res. II Top. Stud. Oceanogr. 45, 517-567. doi: 10.1016/s0967-0645(97) 00074-x

Skarke, A., Ruppel, C., Kodis, M., Brothers, D., and Lobecker, E. (2014). Widespread methane leakage from the seafloor on the northern US Atlantic margin. Nat. Geosci. 7, 657-661. doi: 10.1038/ngeo2232

Sommer, S., Gutzmann, E., and Pfannkuche, O. (2007). Sediments hosting gas hydrates: oases of metazoan meiofauna. Mar. Ecol. Prog. Ser. 337, 27-37. doi: $10.3354 /$ meps337027

Torres, M. E., McManus, J., Hammond, D. E., De Angelis, M. A., Heeschen, K. U., Colbert, S. L., et al. (2002). Fluid and chemical fluxes in and out of sediments hosting methane hydrate deposits on hydrate ridge, or, I: hydrological provinces. Earth Planet. Sci. Lett. 201, 525-540. doi: 10.1016/ s0012-821x(02)00733-1

Valentine, D. L., Jastner, M., Wardlaw, G. D., Wang, X., Purdy, A., and Bartlett, D. H. (2005). Biogeochemical investigations of marine methane seeps, Hydrate Ridge, Oregon. J. Geophys. Res. 110:G02005. doi: 10.1029/2005JG0 00025

Weber, T. C., Mayer, L. A., Beaudoin, J., Jerram, K., Shedd, W., and Rice, G. (2012). Mapping gas seeps with the deepwater multibeamechosounder on okeanos explorer. Oceanography 25(Suppl. 1), 54-55.

Wyrtki, K. (1962). The oxygen minima in relation to ocean circulation. Deep Sea Res. 9, 11-23. doi: 10.1242/jeb.060236 doi: 10.1016/0011-7471(62)90243-7

Conflict of Interest: The authors declare that the research was conducted in the absence of any commercial or financial relationships that could be construed as a potential conflict of interest.

Copyright (c) 2020 Wagner, Smart and German. This is an open-access article distributed under the terms of the Creative Commons Attribution License (CC BY). The use, distribution or reproduction in other forums is permitted, provided the original author(s) and the copyright owner(s) are credited and that the original publication in this journal is cited, in accordance with accepted academic practice. No use, distribution or reproduction is permitted which does not comply with these terms. 